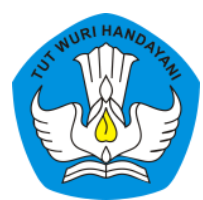

Page: $331-352$

\title{
PENINGKATAN KETERAMPILAN MENULIS PUISI MELALUI PENGGUNAAN MEDIA GAMBAR DAN GLOSARIUM DIKSI PESERTA DIDIK SMPN 6 BONTANG
}

\author{
Kartini \\ Sekolah Menengah Pertama Negeri 6 Kota Bontang, Kalimantan Timur, Indonesia \\ Contributor Email: kartinihanumdiani@gmail.com
}

Received: Dec 29, 2020

Accepted: Jul 02, 2021

Published: Jul 30, 2021

Article Url: https://ojsdikdas.kemdikbud.go.id/index.php/didaktika/article/view/177

\begin{abstract}
The problem in this research is the low poetry writing skills of the VIII grade student sof State Junior High School 6 Bontang. This type of research is classroom action research. Retrieval of data using observation, tests, and interviews. The author conducted two treatments in this study. The first without using media and the second using image media and dictionaries glossary. Based on the results of the study, it can be stated that learning using image media and dictionaries can increase the activeness and skills of writing poetry for VIII grade students. The skill of writing poetry in students has increased, we can see from the average score of the students. In the initial conditions the average value is 40, in the first cycle it increases to an average of 60, (still not reaching the KKM value) in the second cycle it has increased quite significantly to an average value of 85 . Thus it can be said that the application of image media and dictionaries glossary is quite significant in improving the poetry writing skills of grade VIII students of SMP Negeri 6 Bontang.
\end{abstract}

Keywords: Skill; Writing Poetry; Pictures and Dictionaries; Glossary 


\begin{abstract}
Abstrak
Permasalahan dalam penelitian ini adalah rendahnya keterampilan menulis puisi peserta didik kelas VIII Sekolah Menengah Pertama Negeri 6 Bontang. Jenis penelitian ini adalah penelitian tindakan kelas. Pengambilan data menggunakan observasi, tes, dan wawancara. Penulis melakukan dua perlakuan dalam penelitian ini. Yang pertama tampa menggunakan media dan yang kedua menggunakan media gambar dan glosarium diksi. Hasil penelitian menunjukkan bahwa pembelajaran dengan menggunakan media gambar dan glosarium diksi dapat meningkatkan keaktifan dan keterampilan menulis puisi peserta didik kelas VIII. Keterampilan menulis puisi pada peserta didik mengalami peningkatan dapat kita lihat dari nilai rata-rata peserta didik. Pada kondisi awal rata-rata nilai 40, di siklus I meningkat menjadi rata-rata 60, (masih belum mencapai nilai KKM) pada siklus II mengalami peningkatan cukup signifikan menjadi rata-rata nilai 85. Dapat dikatakan bahwa penerapan media gambar dan glosarium diksi cukup signifikan dalam meningkatkan keterampilan menulis puisi peserta didik kelas VIII SMP Negeri 6 Bontang.
\end{abstract}

Kata Kunci: Keterampilan; Menulis Puisi; Gambar; Glosarium Diksi

\title{
A. Pendahuluan
}

Minat baca peserta didik kelas VIII B Sekolah Menengah Pertama Negeri 6 Kota Bontang yang rendah berimbas pada terbatasnya perbendaharaan kata peserta didik. Terutama kata kiasan yang biasa digunakan ketika menulis puisi. Keterbatasan perbendaharaan kata itulah yang menyebabkan rendahnya nilai keterampilan menulis puisi pada peserta didik kelas VIIIB. Selain itu, ketika guru memberikan tugas menulis puisi, banyak diantara peserta didik yang mengeluh dan tidak menginginkan tugas tersebut. Peserta didik kurang tertarik untuk menulis puisi, kurang terpancing untuk berimajinasi dalam menulis puisi, dan menganggap menulis puisi itu sulit sehingga kurang serius dalam menulis puisi. Peserta didik kurang antusias mengikuti pembelajaran menulis puisi. Minat dan antusias peserta didik terhadap pembelajaran menulis puisi ini tergolong rendah.

Selain masalah di atas, kemampuan peserta didik dalam menulis puisi masih rendah juga karena beberapa faktor, yakni (1) peserta didik bingung menentukan tema; (2) peserta didik sulit menuangkan ide dan 
perasaannya dalam bentuk puisi; dan (3) peserta didik masih kesulitan merangkai kata-kata agar menjadi puisi. Tiga faktor tersebut disebabkan keterbatasan wawasan dan perbendaharaan kata.

Kualitas proses dalam menulis puisi juga tergolong rendah. Ada beberapa faktor yang mengakibatkan rendahnya kualitas proses pembelajaran menulis puisi, yaitu (1) peserta didik masih kurang aktif selama pembelajaran; (2) peserta didik kurang mencermati penjelasan yang diberikan guru; dan (3) peserta didik kurang antuasis selama pembelajaran (Syamsi, 2012).

Kualitas proses dan hasil pembelajaran yang rendah menyebabkan nilai menulis puisi pada peserta didik kelas VIII B di Sekolah Menengah Pertama Negeri 6 Kota Bontang belum memenuhi KKM sebesar 72, nilai rata-rata peserta didik 64 . Hasil tersebut sesuai dengan hasil pratindakan di kelas VIII B dan wawancara dengan rekan guru mata pelajaran Bahasa Indonesia yang mengajar dijenjang yang sama di kelas yang berbeda. Kesulitan menentukan tema dan merangkai kata dalam bentuk larik-larik puisi menyebabkan keterampilan menulis puisi peserta didik rendah.

Hasil wawancara dan observasi menunjukkan bahwa terdapat permasalahan dalam pembelajaran menulis puisi di kelas VIII B Sekolah Menengah Pertama Negeri 6 Kota Bontang. Kurangnya motivasi dan variasi model serta metode mengajar yang digunakan guru menjadi penyebab masalah di atas.

Pembelajaran menulis puisi dengan membiarkan peserta didik menulis puisi tanpa arahan atau variasi model pembelajaran, membuat peserta didik kesulitan menuangkan ide-ide kreatifnya dalam puisi (Dahliana, Taufina, Nasrul, \& Sukandar, 2019). Peran guru dalam menerapkan model atau media pembelajaran menjadi salah satu unsur penting untuk meningkatkan minat peserta didik dalam belajar.

Berdasarkan masalah di atas penulis berusaha mencari solusi dengan menggunakan media pembelajaran hasil karya penulis sendiri. Hal tersebut didorong oleh kesadaran bahwa pengajaran sastra memiliki banyak manfaat. Pembelajaran sastra yang tepat dapat membantu proses pendidikan secara 
lengkap dan paripurna bila cakupannya meliputi empat manfaat, yaitu (a) melatih kebiasaan berbahasa yang baik,(b) membiasakan membaca informasi budaya, (c) mengembangkan cipta dan rasa, dan (d) membentuk karakter dengan sentuhan empati. (Rahmanto, 2004: 16-25).

Saat ini masih ada guru yang kurang memperhatikan manfaat pembelajaran sastra yang berimbas pada rendahnya keterampilan sastra pada peserta didik. Kualitas pengajaran sastra menjadi rendah karena berbagai faktor, di antaranya kurikulum, sarana belajar dan guru. Sarana belajar yang baik dan kreativitas guru menjadi pendukung proses kreatif menulis puisi yang baik untuk peserta didik. Metode atau media variatif akan memunculkan minat dan semangat belajar puisi pada peserta didik. (Semi, 2002: 134).

Penggunaan model pembelajaran dan media pembelajaran merupakan solusi untuk mencapai tujuan pembelajaran (Rahmi, et.al., 2019). Model atau media pembelajaran juga harus disesuaikan dengan kondisi peserta didik, sarana pendukung di sekolah dan mudahnya untuk digunakan oleh rata-rata peserta didik. Kualitas proses dan hasil yang optimal menjadi indikator dalam kriteria keberhasilan pembelajaran (Sudjana, 2017; Yusrizal \& Hanif, 2017). Proses pembelajaran menulis puisi yang benar akan memaksimalkan potensi peserta didik. Proses ini tak terlepas dari cara guru melakukan pendekatan kepada peserta didik baik secara umum maupun per pribadi. Proses pembelajaran yang baik akan meningkatkan pemahaman peserta didik terhadap materi pelajaran yang dijelaskan oleh guru. Pemahaman tersebut tentunya akan memengaruhi keterampilan atau hasil belajar peserta didik.

Kedua kriteria tersebut saling berhubungan karena pembelajaran tidak semata-mata menitik beratkan pada hasil, tetapi juga menitik beratkan pada proses. Indikator proses pembelajaran berlangsung secara optimal dapat dilihat dari berbagai faktor, yaitu peserta didik belajar dengan penuh semangat, aktif selama pembelajaran, mampu mengemukakan pendapat, 
antusias selama pembelajaran, dan terlibat dalam pemecahan masalah. Indikator keberhasilan berlangsung secara optimal.

\section{B. Metode}

Metode yang digunakan dalam pengumpulan data pada penelitian ini berupa penelitian tindakan yang dilaksanakan di dalam kelas dan biasa disebut dengan nama Penelitian Tindakan Kelas atau PTK. Penelitian dilaksanakan dalam siklus pada jenjang kelas tertentu dengan menggunakan media atau metode sebagai solusi terhadap permasalahan yang ada.

Metode penelitiannya mengikuti prinsip-prinsip penelitian tindakan yang terdiri dari 4 (empat) tahap yaitu, perencanaan, pelaksanaan tindakan, observasi yang memuat pencatatan, perekaman, interview serta refleksi. Mulai tahap perencanaan sampai tahap refleksi menjadi unsur untuk membentuk sebuah siklus, yaitu putaran kegiatan beruntun yang kembali ke langkah semula. Menyusun rancangan penelitian sampai pada tahap refleksi merupakan rangkaian dari satu siklus. Bentuk tindakan penelitian ini adalah siklus tersebut. Alur desain PTK yang digambarkan sebagai berikut.

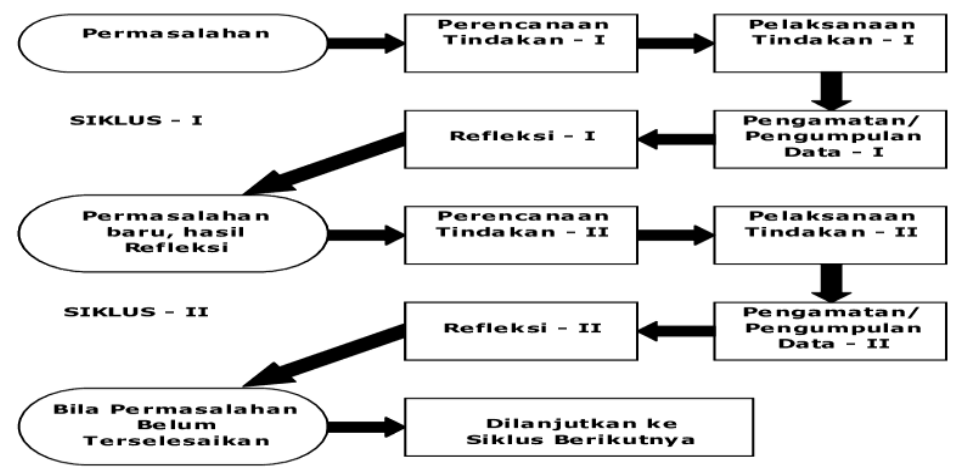

Gambar I : Desain PTK

Sesuai dengan paradigma penelitian tindakan yang dilakukan dalam kelas, dan penelitian ini terdapat 4 (empat) instrumen pokok yang digunakan untuk mengumpulkan data, yaitu lembar/daftar observasi, pedoman wawancara, kamera, dan instrumen tes tertulis. Fungsi masing-masing instrumen adalah sebagai berikut. (1) Daftar/lembar observasi digunakan untuk 
mengumpulkan data mengenai perhatian, cara, kesungguhan, keberanian, tanggung jawab peserta didik, kerajinan peserta didik, dalam mengikuti proses belajar menulis puisi dengan menggunakan media gambar dan glosarium diksi melalui analisis terhadap hasil keterampilan peserta didik. (2) Pedoman wawancara digunakan untuk lebih memperdalam perhatian, cara, kesungguhan, keberanian, tanggung jawab peserta didik, kerajinan peserta didik melalui analisis materi wawancara. (3) Kamera digunakan untuk merekam semua data dan aktivitas peserta didik selama berlangsungnya proses pembelajaran di dalam dan di luar kelas. (4) Instrumen yang berupa tes tertulis digunakan untuk mengetahui hasil belajar peserta didik dalam aspek kognitif. (5) Observasi, catatan data lapangan, wawancara, hasil tes dan catatan hasil refleksi/diskusi merupakan teknik pengumpulan data dalam penelitian ini yang dilakukan oleh peneliti dan mitra peneliti.

Ketersediaan sarana dan prasarana serta kemampuan yang dimiliki peneliti dan mitra peneliti menjadi dasar dalam menentukan teknik pengumpulan data tersebut. Terdapat sepuluh tema gambar dan glosarium diksi yang disiapkan guru yang dapat dipilih oleh peserta didik pada tindakan di siklus I dan siklus II.
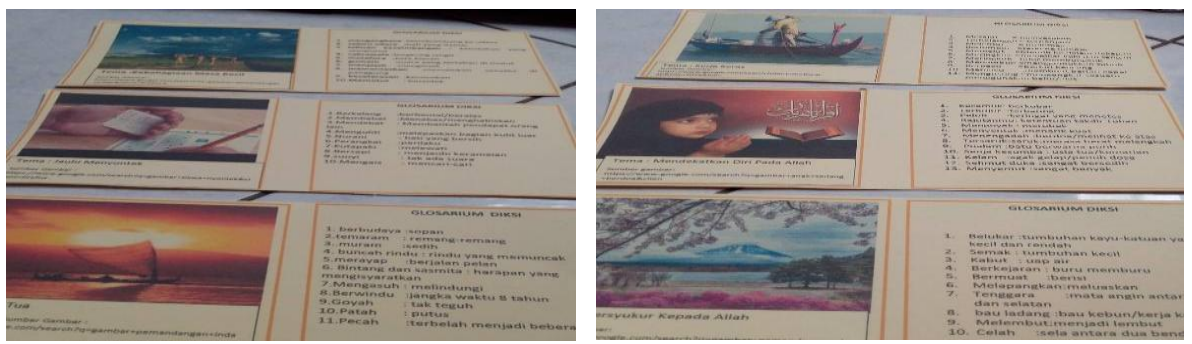

Gambar 2 : Gambar dan Glosarium Diksi

Tabel 1. Kisi-kisi Penilaian Keterampilan Menulis Puisi Menggunakan Gambar dan Glosarium Diksi

\begin{tabular}{clc}
\hline No & \multicolumn{1}{c}{ Aspek yang dinilai } & Bobot \\
\hline 1 & Majas (diksi) & 20 \\
2 & Irama/rima & 20 \\
3 & Kata perlambangan & 20
\end{tabular}


4 Tipografi 20

5 Pengimajian

Total Skor
20

100

Tabel 2. Rubrik Penilaian Keterampilan Menulis dengan Menggunakan Gambar dan Glosarium Diksi

\begin{tabular}{|c|c|c|c|}
\hline No & $\begin{array}{l}\text { Aspek yang } \\
\text { dinilai }\end{array}$ & Rubrik & Bobot \\
\hline \multirow[t]{3}{*}{1} & \multirow[t]{3}{*}{ Majas (diksi) } & Terdapat 10 majas/diksi & 20 \\
\hline & & Terdapat 8 majas/diksi & 15 \\
\hline & & Terdapat 5 majas atau diksi & 10 \\
\hline \multirow[t]{3}{*}{2} & \multirow[t]{3}{*}{ Irama/rima } & Terdapat irama/rima di seluruh bait & 20 \\
\hline & & Terdapat irama/rima di beberapa bait & 15 \\
\hline & & $\begin{array}{l}\text { Hanya satu bait yang menggunakan } \\
\text { irama/rima }\end{array}$ & 10 \\
\hline \multirow[t]{3}{*}{3} & \multirow[t]{3}{*}{$\begin{array}{l}\text { Kata } \\
\text { perlambangan }\end{array}$} & $\begin{array}{l}\text { Dalam satu bait terdapat } 4 \text { kata } \\
\text { perlambangan }\end{array}$ & 20 \\
\hline & & $\begin{array}{l}\text { Dalam satu bait terdapat } 3 \text { kata } \\
\text { perlambangan }\end{array}$ & 15 \\
\hline & & $\begin{array}{l}\text { Dalam satu bait hanya } 1 \text { kata } \\
\text { perlambangan }\end{array}$ & 10 \\
\hline \multirow[t]{3}{*}{4} & \multirow[t]{3}{*}{ Tipografi } & Larik-larik puisi sudah membentuk bait & 20 \\
\hline & & Larik-larik puisi cukup membentuk bait & 15 \\
\hline & & Larik-larik puisi kurang membentuk bait & 10 \\
\hline \multirow[t]{3}{*}{5} & \multirow[t]{3}{*}{ Pengimajian } & $\begin{array}{l}\text { Dalam puisi terdapat imaji visual, auditif } \\
\text { dan tartil }\end{array}$ & 20 \\
\hline & & $\begin{array}{l}\text { Dalam puisi hanya terdapat imaji visual } \\
\text { dan auditif }\end{array}$ & 15 \\
\hline & & Dalam puisi hanya terdapat satu imaji & 10 \\
\hline
\end{tabular}




\section{Hasil dan Pembahasan}

\section{Hasil}

Tabel 3. Lembar Observasi Aktivitas Peserta didik Selama Proses Pembelajaran Menulis Puisi Menggunakan Gambar dan Glosarium Diksi Siklus I dan II

\begin{tabular}{clcc}
\hline No & \multicolumn{1}{c}{ Aspek yang diamati } & \multicolumn{2}{c}{ Siklus } \\
\hline 1 & $\begin{array}{l}\text { Peserta didik sungguh-sungguh dalam pembelajaran } \\
\text { menulis puisi dengan adanya media gambar dan } \\
\text { glosarium diksi }\end{array}$ & 3 & 4 \\
2 & $\begin{array}{l}\text { Peserta didik bersemangat dalam } \\
\text { mengungkapkan gagasannya dengan adanya media } \\
\text { gambar dan Glosarium Diksi }\end{array}$ & 3 & 4 \\
3 & $\begin{array}{l}\text { Peserta didik mempunyai antusiasme/ minat tinggi } \\
\text { dalam menulis puisi dengan adanya media } \\
\text { gambardan glosarium diksi } \\
4\end{array}$ & $\begin{array}{l}\text { Peserta didik aktif berpartisipasi dalam diskusi dengan } \\
\text { adanya media gambardan glosarium diksi }\end{array}$ & 3 \\
5 & $\begin{array}{l}\text { Peserta didik merasa termotivasi dan tertarik dalam } \\
\text { pembelajaran menulis puisi dengan adanya media } \\
\text { gambardan glosarium diksi }\end{array}$ & 3 \\
6 & $\begin{array}{l}\text { Peserta didik saling berkompetisi menulis puisi dengan } \\
\text { adanya media gambardan glosarium diksi }\end{array}$ & 3 \\
\hline
\end{tabular}

Keterangan : 4 =sangat baik, 3=baik, 2=cukup, 1=kurang

Tabel 4. Lembar Observasi Aktivitas Guru Selama Proses Pembelajaran Menulis Puisi dengan Menggunakan Gambar dan Glosarium Diksi Siklus I dan II

\begin{tabular}{|c|c|c|c|c|}
\hline \multirow[b]{2}{*}{ No } & \multirow[b]{2}{*}{ Aspek yang diamati } & \multicolumn{3}{|c|}{ Siklus } \\
\hline & & $\begin{array}{l}\text { Tanpa } \\
\text { media }\end{array}$ & 1 & 2 \\
\hline \multirow[t]{3}{*}{$\mathrm{I}$} & KEGIATAN PENDAHULUAN & & & \\
\hline & $\begin{array}{l}\text { 1. Guru membuka pelajaran dengan } \\
\text { salam, berdoa, mengecek kehadiran } \\
\text { peserta didik }\end{array}$ & 4 & 4 & 4 \\
\hline & $\begin{array}{l}\text { 2. Guru menuliskan topik } \\
\text { pembelajaran menyampaikan tujuan } \\
\text { pembelajaran }\end{array}$ & 4 & 4 & 4 \\
\hline
\end{tabular}


3. Guru memberikan apersepsi dan

$3 \quad 3 \quad 4$ motivasi

\section{KEGIATAN INTI}

1. Guru memberikan penjelasan materi $\quad \begin{array}{llll}3 & 3 & 4\end{array}$ puisi yaitu unsur-unsur puisi

2. Guru menunjukkan media gambar dan Glosarium diksi, beserta contoh puisi yang dikembangkan dari gambar dan glosarium diksi

3. Guru menggali pengetahuan awal peserta didik dengan bertanya jawab kepada peserta didik mengenai gambar dan glosarium diksi

4. Guru menjelaskan gambar dan glosarium diksi kepada peserta didik

5. Guru memberikan bimbingan kepada peserta didik menulis puisi

III KEGIATAN PENUTUP

1. Guru memberikan bahan tindak lanjut dan pesan moral

2. Guru menutup kegiatan pembelajaran

Keterangan : 4 =sangat baik, 3=baik, 2=cukup, 1=kurang

Grafik I. Hasil Tes Keterampilan Menulis Puisi pada Kondisi Awal

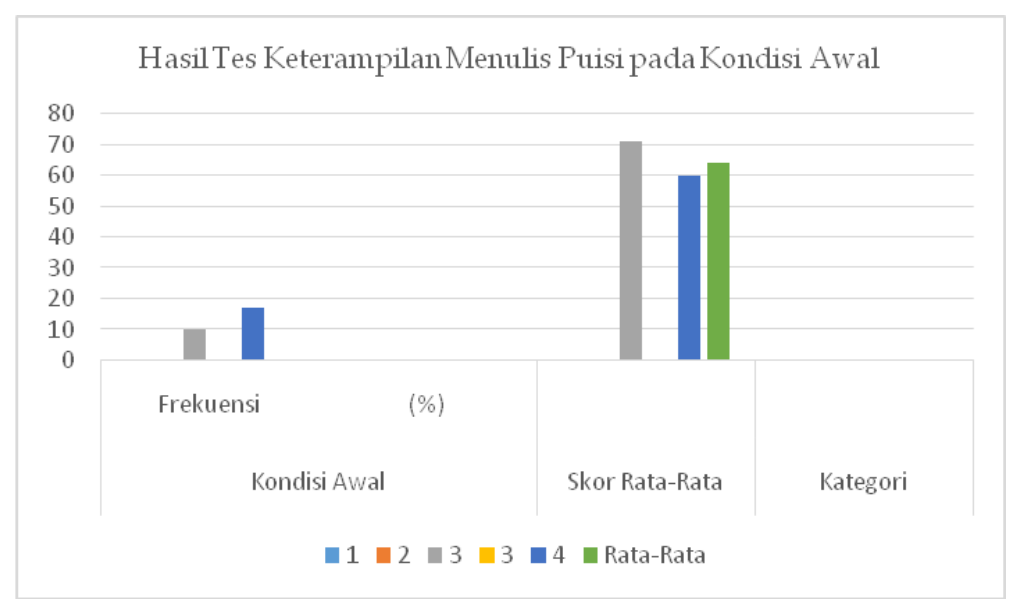


Grafik 2. Rekapitulasi Data Distribusi Frekuensi Keterampilan Menulis Puisi Siklus I

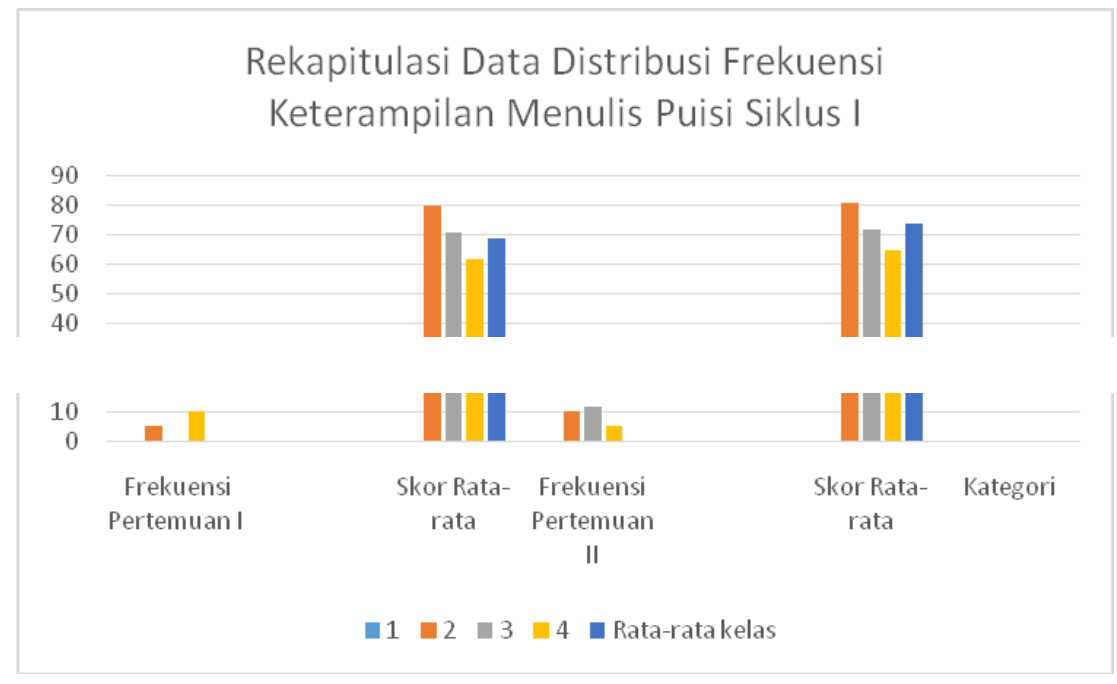

Grafik 3. Rekapitulasi Data Distribusi Frekuensi Keterampilan Menulis Siklus II

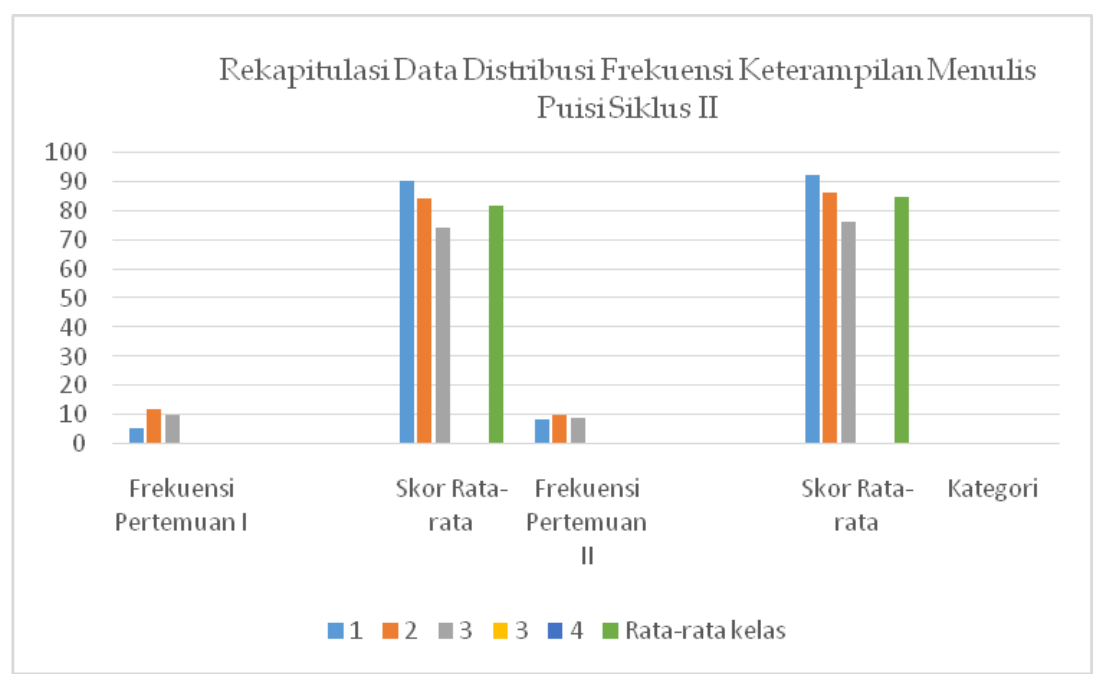

\section{Pembahasan}

Hasil observasi dan survei kondisi awal pada peserta didik kelas VIII B Sekolah Menengah Pertama Negeri 6 Kota Bontang yang berjumlah 27 peserta didik menjadi dasar menentukan strategi pembelajaran. 
Penggunaan media gambar dan glosarium diksi adalah upaya untuk memperbaiki dan memecahkan masalah pada pembelajaran menulis puisi.

Siklus I diawali dengan perencanaan tindakan yang disusun berdasarkan permasalahan utama dalam pembelajaran menulis puisi, yaitu kemampuan peserta didik dalam menulis puisi masih rendah. Nilai yang diperoleh peserta didik masih jauh dari batas tuntas yang ditetapkan. Penerapan gambar dan glosarium diksi dalam pembelajaran ini mempertimbangkan proses penggalian ide yang kreatif melalui latihan. Ada lima aspek yang penulis gunakan untuk mengukur keterampilan menulis puisi peserta didik kelas VIII Byaitu (1) aspek majas/diksi, (2) irama/rima, (3) kata perlambangan, (4) tipografi, dan (6)pengimajian. Setiap aspek diberi bobot tertinggi 20 dan bobot terendah 10. Pelaksanaan siklus I terdiri atas tiga kegiatan, yaitu kegiatan awal, kegiatan inti, dan kegiatan penutup. Setiap kegiatan pembelajaran menulis puisi berlandaskan pada RPP. Pembelajaran menulis puisi pada siklus I menggunakan media gambar dan glosarium diksi. Selama pembelajaran, peneliti mengamati keaktifan dan perhatian peserta didik saat proses pembelajaran berlangsung. Hal tersebut untuk mengetahui kualitas proses pembelajaran menulis puisi.

Pembelajaran menulis puisi diawali dengan kegiatan meliputi (1) guru membuka pelajaran dengan salam, berdoa, mengecek kehadiran peserta didik; (2) Guru menuliskan topik pembelajaran dan menyampaikan tujuan pembelajaran; (3) Guru memberikan apersepsi dan motivasi. Pada kegiatan awal, guru memotivasi peserta didik agar aktif dalam tanya jawab dan memperhatikan penjelasan guru. Pada kegiatan inti pembelajaran menulis puisi meliputi (1) guru memberikan penjelasan materi puisi yaitu unsur-unsur puisi; (2) Guru menunjukkan media gambar dan glosarium diksi beserta contohnya yang dikembangkan dari gambar dan glosarium diksi; (3) Guru menggali pengetahuan awal peserta didik dengan bertanya jawab kepada peserta didik mengenai gambar dan glosarium diksi; (4) Guru 
menjelaskan gambar dan glosarium diksi kepada peserta didik; (5) Guru memberikan bimbingan kepada peserta didik cara menulis puisi dengan meminta peserta didik memperhatikan komentar dari peserta didik lain mengenai permasalahan yang ada, menstimulus peserta didik mengembangkan daya khayalnya melalui media gambar dan glosarium diksi, membimbing peserta didik merangkai kata-kata yang akan ditulis dalam puisi berdasarkan gambar yang dipilih dalam kelompok tersebut; (6) Guru berkeliling memberikan arahan kepada peserta didik yang mengalami kesulitan dalam menuliskan larik-larik puisi; (7) Setiap kelompok memilih perwakilan untuk memaparkan hasil puisinya, dan kelompok lain mengomentari puisi yang sedang dipaparkan; (8) Guru dan peserta didik lain memperbaiki diksi yang kurang tepat pada puisi yang sedang dipresentasikan, kemudian pesertadidik mengganti diksi yang kurang tepat menjadi diksi yang tepat sesuai dengan perbaikan saat presentasi.

Kegiatan akhir meliputi (1) guru dan peserta didik melakukan refleksi atas pembelajaran; (2) Guru merencanakan kegiatan berikutnya; dan (3) Guru memberikan penghargaan kepada peserta didik. Pembelajaran menulis puisi menggunakan media gambar dan glosarium diksi pada siklus I telah menunjukkan adanya peningkatan dibandingkan saat pratindakan. Keaktifan peserta didik dilihat dari keaktifan bertanya dan keterlibatan dalam pemecahan masalah. Pada tahap ini peserta didik yang aktif dan terlibat dalam memecahkan masalah hanya beberapa saja.

Pada siklus I keaktifan peserta didik telah mengalami peningkatan dibandingkan pratindakan. Akan tetapi, Perhatian peserta didik terhadap guru saat menyampaikan materi masih kurang karena hanya ada beberapa peserta didik yang memperhatikan selebihnya masih melakukan aktivitas lain.

Dengan demikian, perhatian peserta didik mengalami peningkatan dibandingkan pratindakan. Keaktifan peserta didik dilihat dari kemampuan peserta didik memahami dan mengikuti petunjuk guru, tugas dapat diselesaikan, memanfaatkan sumber belajar, dan menguasai 
tujuan pembelajaran yang ditetapkan. Saat penggunaan media gambar dan glosarium diksi, belum sepenuhnya peserta didik memahami cara penggunaan media tersebut. Selain itu, dalam kelompok, peserta didik belum mampu bekerja sama dengan baik. Saat batas waktu penyelesaian tugas, peserta didik tampak tergesa-gesa menyelesaikan puisinya.

Dengan demikian, kegiatan peserta didik dalam pembelajaran menulis puisi mengalami peningkatan dibandingkan prasiklus. Pada siklus I mengalami peningkatan kualitas proses dalam pembelajaran menulis puisi. Hasil nilai lima aspek berdasarkan skor rata-rata kelas, pada siklus I di dua kali tatap muka mengalami peningkatan 100\% menjadi rata-rata 10. Untuk aspek irama/rima meningkat $50 \%$ menjadi rata-rata 15. Pada aspek kata perlambangan saat pratindakan rata-rata skor kelas hanya mendapat nilai 5. Pada siklus I mengalami peningkatan $100 \%$ menjadi rata-rata nilai 10 .

Di aspek tipografi saat pratindakan rata-rata skor kelas mendapat nilai 10, dan mengalami peningkatan $50 \%$ pada siklus I Untuk aspek pengimajianpada saatpratindakan rata-rata skor kelas mendapat nilai 10 dan pada siklus I belum mengalami peningkatan. Untuk gabungan nilai kelima aspek di atas yang terintegrasi menjadi nilai keterampilan menulis puisi, didapatkan data untuk pertemuan pertama yang mendapat kategori kurang sebanyak 10 peserta didik mendapat nilai 62 dan di pertemuan kedua terdapat 5peserta didikmendapat nilai 65. Untuk kategori cukup pada pertemuan pertama ada 12 peserta didik mendapat nilai 71 dan di pertemuan kedua terdapat 12 peserta didik mendapat nilai 72. Pada kategori baik di pertemuan pertama terdapat 5 peserta didik mendapatkan nilai 80 dan di pertemuan kedua terdapat 10 peserta didik mendapatkan nilai 81 . Belum ada peserta didik yang mendapat nilai istimewa/ sangat baik. Nilai rata-rata kelas di pertemuan pertama 69 dan di pertemuan kedua 74 .

Hasil pengamatan siklus I menunjukkan bahwa pembelajaran menulis puisi menggunakan media gambar dan glosarium diksi belum 
mengalami kenaikan yang cukup berarti dari kualitas proses dan kemampuan peserta didik. Faktor penyebab hal tersebut yaitu (1) terbatasnya gambar yang disajikan sehingga peserta didik masih terbatas kreativitasnya, (2) tahap-tahap cara menggunakan media gambar dan glosarium belum dimaksimalkan, (3) keaktifan peserta didik, perhatian peserta didik dalam pembelajaran masih kurang, dan (4) kemampuan peserta didik dalam menulis puisi pada pertemuan pertama belum mencapai KKM yang telah ditentukan dan di pertemuan kedua telah sesuai KKM tapi belum sesuai harapan.

Tujuan pembelajaran menulis puisi belum terpenuhi diketahui setelehmenganalis data yang didapatkan. Tindaklanjut refleksi dari kekurangan selama pembelajaranadalah (1) menambah gambar agar kreativitas peserta didik tidak terbatas dan (2) semua tahap cara menggunakan media gambar dan glosarium diksi harus dilaksanakan sesuai dengan porsinya.

Peserta didik perlu lebih aktif selama proses pembelajaran, perhatian peserta didik dalam pembelajaran juga baik, dan keterlaksanaan peserta didik dalam pembelajaran perlu lebih meningkat sehingga kualitas proses maupun kemampuan peserta didik dapat meningkat. Setelah mendata hasil refleksi selanjutnya diputuskan perlu adanya siklus berikutnya untuk mencapai tujuan pembelajaran menulis puisi menggunakan media gambar dan glosarium diksi. Pelaksanaan siklus II dilakukan dengan mengkaji ulang RPP sesuai dengan permasalahan yang ditemukan pada siklus I.

Pada perencanaan Tindakan siklus II, peneliti memfokuskan pada aspek yang membuat nilai peserta didik menjadi lebih baik. Peneliti merencanakan RPP yang akan diterapkan dalam pembelajaran. Peneliti juga menyediakan media pembelajaran dan bahan pelajaran yang dibutuhkan untuk pelaksanaan tindakan siklus II.

Pelaksanaan siklus II sesuai dengan perencanaan. Pelaksanaan tindakan siklus II terdiri atas tiga kegiatan, yaitu kegiatan awal, kegiatan 
inti, dan kegiatan penutup. Tiga kegiatan pada pembelajaran siklus II disusun berdasarkan kekurangan pada siklus I.

Pada siklus I terdapat kekurangan dalam penelitian yang meliputi peserta didik masih kesulitan menuliskan larik-larik puisinya karena gambar yang tersedia belum variatif, peserta didik kesulitan menuliskan majas, dan peserta didik masih kesulitan menuliskan kata-kata konotasi dalam puisinya. Siklus II dilaksanakan berdasarkan rancangan perbaikan pelaksanaan siklus I. Keoptimalan siklus II akan dilakukan dengan memberikan gambar yang lebih variatif dan lebih memperhatikan tahapan-tahapan penggunaan media gambar dan glosarium diksi agar dilaksanakan lebih optimal. Siklus II masih menggunakan media gambar dan glosarium diksi.

Selain itu, materi yang akan lebih ditekankan adalah majas dan katakata perlambangan. Kegiatan siklus II terdiri dari kegiatan awal, kegiatan inti, dan kegiatan penutup. Kegiatan awal pembelajaran menulis puisi meliputi kegiatanberikut. (1) Guru mengucapkan salam, mengecek kehadiran peserta didik, dan menanyakan kesiapan peserta didik dalam pembelajaran menulis puisi; (2) Guru mengevaluasi pembelajaran sebelumnya; (3) Guru menjelaskan ulang materi sebelumnya. Pada kegiatan awal, guru memotivasi peserta didik agar aktif dalam tanya jawab dan memperhatikan penjelasan guru. Kegiatan inti pembelajaran menulis puisi meliputi(1) guru memberikan contoh puisi; (2) Guru memberikan kesempatan peserta didik untuk bertanya; (3) Guru membimbing peserta didik mengidentifikasi masalah, peserta didik dibagi menjadi beberapa kelompok, guru meminta perwakilan kelompok untuk merespon puisi yang ada, guru meminta peserta didik memperhatikan komentar dari peserta didik lain mengenai permasalahan yang ada; (4) Peserta didik mengembangkan daya khayalnya melalui media gambar dan glosarium diksi, peserta didik merangkai kata-kata yang akan ditulis dalam puisi berdasarkan gambar yang dipilih dalam kelompok tersebut; (5) Guru berkeliling memberikan arahan kepada peserta didik yang mengalami 
kesulitan dalam menuliskan larik-larik puisi, peserta didik dapat bertanya kepada guru atau teman sekelompoknya; (6) Setiap kelompok memilih perwakilan untuk mempresentasikan hasil puisinya, kelompok lain mengomentari puisi yang sedang dipresentasikan, guru dan peserta didik lain memperbaiki diksi yang kurang tepat pada puisi yang sedang dipresentasikan; (7) Peserta didik mengganti diksi yang kurang tepat menjadi diksi yang tepat sesuai dengan perbaikan saat presentasi.

Kemudian, kegiatan akhir meliputi (1) guru dan peserta didik melakukan refleksi atas pembelajaran; (2) guru merencanakan kegiatan berikutnya; dan (3) Guru memberikan penghargaan kepada peserta didik. Kualitas proses pembelajaran menulis puisi dilihat dari keaktifan peserta didik, perhatian peserta didik, dan keterlaksanaan peserta didik menggunakan lembar pengamatan. Kualitas proses pada siklus II peserta didik mengalami perubahan tingkah laku.

Hasil nilai lima aspek berdasarkan skor rata-rata kelas. Nilai aspek majas di siklus dua mengalami peningkatan $25 \%$ bila dibandingkan dengan siklus I. Aspek irama/rima di silus II kembali mengalami peningkatan $50 \%$ menjadi rata-rata mendapat nilai 20.Aspek kata di siklus II kembali meningkat 50\% menjadi rata-rata 15, demikian juga untuk aspek tipografi meningkat kembali $50 \%$ di silus II. Aspek pengimajian rata-rata skor kelas meningkat sebanyak 50\% menjadi rata-rata skor kelas 10.

Nilai hasil gabungan kelima aspek diketahui bahwa tidak ada lagi peserta didik yang mendapat kategori kurang, baik di pertemuan pertama maupun pertemuan kedua. Kategori cukup sebanyak 10 peserta didik, dengan nilai 74 pada pertemuan pertama dan 9 peserta didik mendapat nilai 76 pada pertemuan kedua. Kategori baik sebanyak 12peserta didik mendapat nilai 84 pada pertemuan pertama dan 10 peserta didiknendapat nilai 86 pada pertemuan kedua. Untuk kategori sangat baik sebanyak 5peserta didik mendapat nilai 90 pada pertemuan pertama dan 8 peserta didik mendapat nilai 92 pada pertemuan kedua. Rata-rata nilai 
keterampilan peserta didik di pertemuan pertama 81,4 dan di pertemuan kedua 84,4 . Penilaian peserta didik saat pembelajaran berdasarkan lembar penilaian proses pembelajaran menggunakan media gambar dan glosarium diksi pada siklus II mengalami peningkatan. Peneliti mengamati peserta didik selama pembelajaran dilihat dari keaktifan, dan perhatian peserta didik.

Keaktifan peserta didik selama pembelajaran berlangsung dapat diketahui dari keaktifan bertanya, melibatkan diri dalam pemecahan masalah, melaksanakan tugas, dan melaksanakan diskusi bersama kelompok. Keaktifan peserta didik di siklus II mengalami kenaikan dengan kategori baik. Perhatian peserta didik saat proses pembelajaran berlangsung ditandai dengan sebagian besar peserta didik memperhatikan materi yang disampaikan oleh guru. Oleh karena itu, perhatian peserta didik selama pembelajaran sudah meningkat signifikan. Keaktifan peserta didik dalam pembelajaran diketahui dari semua peserta didik memperhatikan ketentuan yang disampaikan oleh guru, melaksanakan setiap kegiatan selama pembelajaran, dan semua tugas dapat diselesaikan. Kemampuan menulis puisi berdasarkan hasil menulis puisi peserta didik pada siklus II menunjukkan ada peningkatan dibandingkan siklus I.

Pencapaian nilai peserta didik yang mencapai KKM berdasarkan pada peningkatan hasil kemampuan menulis puisi diimbangi dengan pemahaman unsur-unsur puisi dalam mencipta puisi. Namun, tidak semua peserta didik memperhatikan unsur-unsur puisi dalam mencipta puisi. Hal tersebut terbukti pada siklus II masih ada beberapa peserta didik yang tidak memperhatikan unsur-unsur puisi. Hasil pengamatan pada siklus II menunjukkan bahwa pembelajaran menulis puisi menggunakan media gambar dan glosarium diksi sudah mengalami kenaikan yang cukup berarti.

Hal tersebut ditandai beberapa hal berikut. (1) Rata-rata peserta didik telah memperoleh nilai di atas KKM mencapai $90 \%$ atau 25 peserta didik dengan nilai rata-rata 84,4. (2) Keaktifan peserta didik, perhatian, 
dan antusias peserta didiksudah memenuhi ketercapaian indikator, yaitu 80\%. Data di atas menunjukkantindakan pada siklus II dikatakan berhasil. Nilai rata- rata sudah mencapai batas ketuntasan.

Dengan demikian, pembelajaran menulis puisi sudah berhasil diterapkan di kelas VIII-B SMP Negeri 6 Kota Bontang. Peningkatan kualitas proses pembelajaran menulis puisi menggunakan media gambar dan glosarium diksi mengalami kenaikan berdasarkan pada nilai siklus I dan siklus II. Peningkatan kualitas proses selama pembelajaran dinilai dari beberapa indikator, yakni (1) keaktifan peserta didik selama kegiatan pembelajaran, (2) perhatian peserta didik saat guru menjelaskan materi, dan (3) antusias peserta didik dalam kegiatan pembelajaran. Hasil pengamatan pada pratindakan, siklus I, dan siklus II menunjukkan bahwa ketiga indikator tersebut mengalami peningkatan.

Hasil penelitian peningkatan keterampilan menulis puisi menggunakan media gambar dan glosarium diksi menunjukkan bahwa Penelitian Tindakan Kelas (PTK) dapat meningkatkan kualitas pembelajaran. Peningkatan tersebut dapat dilihat dari meningkatnya kemampuan menulis puisi dan kualitas proses pembelajaran peserta didik menggunakan media gambar dan glosarium diksi.

Hal tersebut sesuai dengan pernyataan bahwa PTK perlu dilakukan sebagai pemecahan dalam meningkatkan kondisi belajar (Mulyasa, 2011). Selanjutnya, PTK perlu dilakukan untuk meningkatkan mutu pembelajaran di kelas (Suwandi, 2011). Keberhasilan pembelajaran berdasarkan proses dan hasil pembelajaran yang tercapai (Sudjana, 2017). Media gambar dan glosarium diksi mendorong peserta didik untuk berpikir kreatif dalam proses penulisan puisi dan mampu mengarahkan peserta didik untuk menulis puisi dengan optimal. Penelitian ini menunjukkan bahwa media gambar dan glosarium diksi dapat mengatasi kualitas kemampuan peserta didik menulis puisi berupa kesulitan mengungkapkan ide, memilih diksi, dan merangkai kata menjadi puisi. Kesulitan tersebut dapat diatasi melalui fase-fase yang terdapat dalam 
penggunaan media gambar dan glosarium diksi, yaitu fase ketiga tentang urun gagasan. Hal ini sejalan dengan pernyataan bahwa media gambar dan glosarium diksi memberikan pengetahuan dan pengalaman bahasa dan sastra yang kreatif bagi peserta didik. Dalam menggunakan media gambar dan glosarium diksi tidak hanya peserta didik yang dituntut aktif berolah kreatif, guru pun diharapkan terlibat langsung dalam proses berolah kreatif (Rohayati \& Abidin, 20).

\section{Penutup}

Berdasarkan hasil analisis data dan pembahasan, dapat disimpulkan bahwa proses pembelajaran menulis puisi menggunakan media gambar dan golsarium diksi dapat ditingkatkan dengan cara guru memberikan apresiasi dan motivasi, memberikan penjelasan kepada peserta didik tentang puisi, menunjukkan media gambar dan glosarium diksi, melakukan apersepsi dengan bertanya jawab terkait gambar, menjelaskan gambar, memberikan bimbingan kepada peserta didik, dan memberikan evaluasi menulis puisi. Penggunaan media gambar dan glosarium diksi memunculkan kesungguhan peserta didik dalam pembelajaran menulis puisi, semangat dalam mengungkapkan gagasannya, antusiasme/minat tinggi dalam menulis puisi, aktif berpartisipasi dalam diskusi, rasa termotivasi, tertarik dan saling berkompetisi menulis puisi.

Keterampilan menulis puisi menggunakan media gambar dan glosarium diksi dapat ditingkatkan dengan cara; peserta didik mengamati gambar, menggali pengetahuan awalnya terhadap gambar, menuliskan kata-kata yang sesuai gambar dan mengembangkan ide ke dalam puisi utuh dengan memperhatikan unsur-unsur puisi.

Proses pembelajaran menggunakan media gambar dan glosarium diksi dapat dilakukan di dalam ruangan (indoor) atau di luar ruangan (outdoor). Untuk mengembangkan imajinasi dan kreativitas serta suasana 
yang menyenangkan bagi peserta didik sebaiknya media ini digunakan pada proses pembelajaran di luar ruangan (outdoor).

\section{Ucapan Terima Kasih}

Terima kasih dan penghargaan tertulus penulis sampaikan pada Kepala Sekolah Menengah Pertama Negeri 6 Kota Bontang yang telah memberi motivasi dalam penelitian tindakan kelas ini. Penulis juga menyampaikan ucapan terima kasih kepada seluruh rekan-rekan guru SMP Negeri 6 yang selalu memotivasi dan mendoakan penulis. Semoga karya tulis sederhana ini bermanfaat untuk perkembangan dunia pendidikan.

\section{Daftar Referensi}

Agusrita, Darnis Arif, Rafly Surya Bagaskara, dan Rahmania Yunita. (2020). "Penggunaan Media Gambar untuk Meningkatkan Hasil Belajar Keterampilan Menulis Puisi di Sekolah Dasar". Jurnal Basicedu. Volume Jurnal 4 Nomor 3. Halaman 604-609.

Hilmatunnida, Kartini. (2016). Mewarnai Peradaban dengan Sastra. Karanganyar: Oase Pustaka.

Maulidah, Tsalitsatul. (2020). "Peningkatan Keterampilan Menulis Puisi dengan Media Gambar". Jurnal Kependidikan, Pembelajaran dan Pengembangan, Volume 02, Nomor 01.Halaman 64-70.

Rahmi, R., Fitriati, F., \& Fachraini, S. (2019). An Analysis of Teachers' Perceptions toward the Role of ICT Based Media in Teaching and Learning Process among Primary Schools' Teachers. Jurnal Ilmiah Peuradeun, 7(3), 469-482. doi:10.26811/peuradeun.v7i3.335

Sukoyo. (2018). “Peningkatan Kemampuan Menulis Puisi dengan Metode QuantumTeaching Menggunakan media Gambar Peserta didik Kelas V SDN I Bendosari Ngantru Tulung Agung". Jurnal Pendidikan Profesional. Volume1, Nomor 1.

Suwanto. (2018). Penelitian Tindakan Kelas, Sekolah, dan Best Practice. Surabaya: Pustaka Intermedia.

Suwatno \& Yunus Abidin. (2018). Pembelajaran yang Menarik dan Menantang dalam Konteks Kurikulum 2013. Bandung: Cendikia Press. 
Wahyudi, Danang. (2016). "Peningkatan Keterampilan Menulis Puisi Menggunakan Media Gambar Pada Peserta didik Kelas V SD Negeri Suryodiningratan 2". Jurnal Pendidikan Guru Sekolah Dasar. Edisi 16 Tahun ke-5.

Winarni, Endang Widi. (2018). Teori dan Praktik Penelitian Kuantitatif dan Kualitatif (PTK dan RE D). Jakarta: Bumi Aksara.

Yusrizal, Y., \& Hanif, K. (2017). Increasing of Students' Motivation in Learning Physics Through the Use of Computer Simulation Media Viewed From Parents' Employment Background. Jurnal Ilmiah Peuradeun, 5(2), 201-212. doi:10.26811/peuradeun.v5i2.129 
Vol. 5, No. 2, Juli 2021 